\title{
Ermittlung der verbleibenden Körperschaftsteuer (vgl. R 7.2 KStR 2015)
}

Der Körperschaftsteuersatz beträgt 15 v. H. des zu versteuernden Einkommens (z. v. E.). Zuzüglich der Gewerbesteuer i. H. v. ca. 14 v. H. beläuft sich die Ertragsteuerbelastung von Kapitalgesellschaften auf insgesamt ca. 30 v. H. (unter Berücksichtigung des Solidaritätszuschlags von 5,5 v. H.). Diese Steuerbelastung ist gegenüber der Einkommensteuerbelastung der Gesellschafter (Progressionsbelastung) eindeutig von Vorteil. Aber: dies gilt nur für von der Kapitalgesellschaft thesaurierte Gewinne. Denn im Falle einer Gewinnausschüttung ergibt sich zumindest eine zusätzliche Einkommensteuerbelastung i. H. v. 25 v. H. (§ 32d Abs. 1 EStG).

Die verbleibende KSt kann wie folgt ermittelt werden:

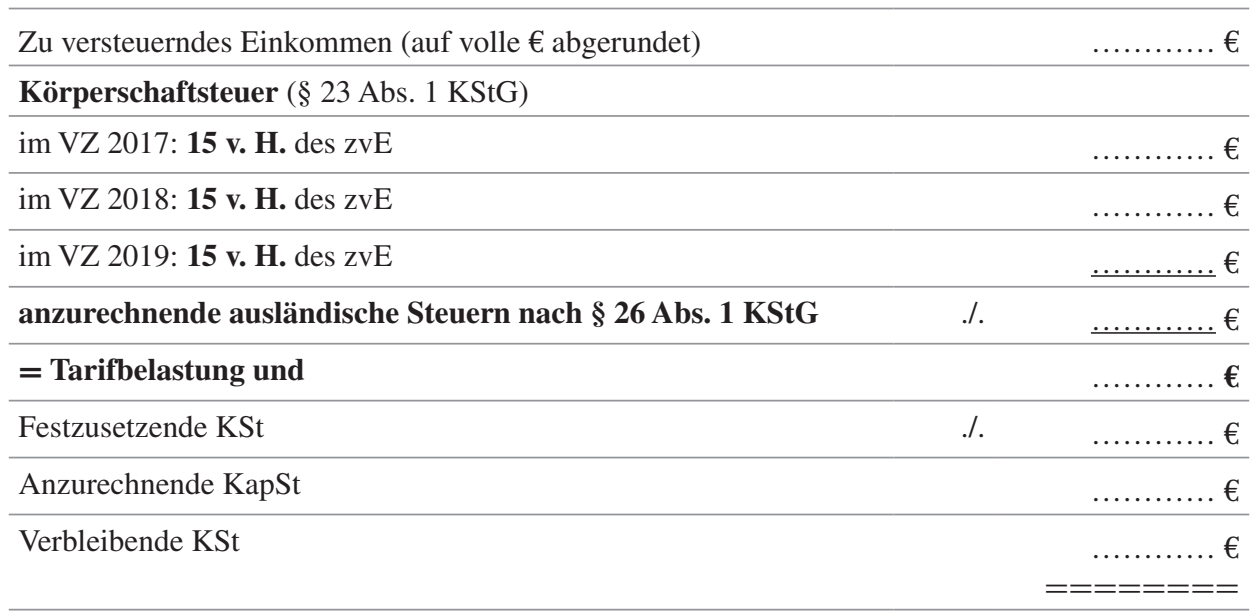

